Trivium: Estudos Interdisciplinares, Ano XIII, Ed. 2. p. 49-61.

http://dx.doi.org/10.18379/2176-4891.2021v2p.49

\title{
Por uma erótica do fim: luto no contexto da pandemia de COVID-19
}

Camila Butinholli Rangel ${ }^{*}$ José Maurício Loures **

\section{Resumo}

Embora a teoria freudiana sobre o luto não tenha trazido maiores explicações sobre seu manejo, psicanalistas como Jacques Lacan e Jean Alouch, desenvolveram fundamentações ainda pouco conhecidas em certos campos e, por vezes, deturpadas, que podem ser aplicadas a contextos clínicos. Através desses estudos e de articulações com obras cinematográficas que retratam o luto, será apresentada a proposta de novos modos de intervenção com o trabalho em ato com o luto no contexto da prática clínica hospitalar, considerando a recente experiência de um dos autores com as Visitas Virtuais de Familiares (VVF's) no Hospital Público de Macaé- HPM/HPMIH.

Palavras-chave: LUTO; MORTE; PSICANÁLISE; PANDEMIA.

\section{For an erotica of the end: mourning in the context of the COVID-19 pandemic}

\begin{abstract}
Although the Freudian theory of grief has not provided further explanations for its management, psychoanalysts such as Jacques Lacan and Jean Alouch have developed foundations that can be applied to clinical contexts, which are still little known in certain fields and, at times, misrepresented. Through these studies and articulations with cinematographic works that portray grief, the proposal for new modes of intervention with the work in action with grief in the context of hospital clinical practice will be presented, considering the recent experience of one of the authors with Virtual Visits of Relatives (VVF's) at the Public Hospital of Macaé- HPM/HPMIH.
\end{abstract}

Keywords: GRIEF; DEATH; PSYCHOANALYSIS; PANDEMIC.

\section{Por una erótica del fin: duelo en el contexto de la pandemia COVID-19}

\section{Resumen}

Aunque la teoría freudiana del duelo no ha dado más explicaciones para su manejo, psicoanalistas como Jacques Lacan y Jean Alouch han desarrollado fundamentos que pueden aplicarse a contextos clínicos, que aún son poco conocidos en determinados campos y, en ocasiones, tergiversados. A través de estos estudios y articulaciones con obras cinematográficas que retratan el duelo, se presentará la propuesta de nuevos modos de intervención con el trabajo en acción con el duelo en el contexto de la práctica clínica hospitalaria, considerando la experiencia reciente de uno de los autores con Visitas Virtuales de Familiares (VVF’s) en el Hospital Público de Macaé- HPM / HPMIH.

\footnotetext{
* Psicóloga, doutoranda em Psicanálise, Saúde e Sociedade (UVA), atua no Hospital Público Municipal de Macaé.

ORCID ID: https://orcid.org/0000-0003-1581-6080

E-mail: butinhollic@gmail.com

** Psicanalista. Docente do Programa de Pós-graduação stricto sensu em Psicanálise, Saúde e Sociedade (UVA).

ORCID ID: https://orcid.org/0000-0003-4374-2779

E-mail: jose.loures@uva.br
} 
Palabras Clave: LUTO; MUERTE; PSICOANÁLISIS; PANDEMIA.

\section{Introdução}

A pandemia nos fez pensar sobre o luto - um afeto inevitável e difícil de elaborar, o que faz com que, muitas vezes, o assunto seja pouco discutido. Como "reação à perda de uma pessoa amada ou de uma abstração que ocupa seu lugar: pátria, liberdade ou um ideal" (Freud,1917[1915]), confia-se que o luto seja superado por um tempo que não podemos determinar, e não se deve perturbá-lo a fim de não causar prejuízos ao estado psíquico do enlutado. Essa fora uma hipótese considerada por Freud após a Primeira Guerra Mundial, as perdas de pessoas queridas, expatriações sofridas, entre outros. Mas, como abordar o luto no contexto atual? Século XXI, Pandemia de Covid-19, grandes avanços tecnológicos para salvar e prolongar vidas, afastamentos abruptos dos contatos humanos, mas nenhuma garantia que nos liberte da angústia ante o desamparo da morte.

Diante desse cenário, o Hospital Público de Macaé- HPM/HPMIH, que atende situações variadas de urgência/emergência, tornou-se referência para internações de pacientes com sintomas moderados/graves de Covid-19. Atuando nesse hospital desde o ano de 2011, a autora acompanhou em 2020, pela primeira vez, a suspensão de visitas presenciais e do acompanhamento in loco dos pacientes por seus cuidadores, trazendo novos sofrimentos para aqueles e seus familiares. Passou-se à utilização das Visitas Virtuais de Familiares (VVF's), um projeto que teve início em junho de 2020, visando substituir as visitas presenciais por meio de videochamadas para uma maior aproximação entre família, paciente e a equipe de cuidado, como recurso para amenizar a angústia pelo distanciamento e todas as demais dificuldades.

Embora a teoria freudiana sobre o luto não tenha trazido maiores explicações sobre seu manejo clínico, psicanalistas como Jacques Lacan (1998) e Jean Alouch (2004), desenvolveram fundamentações psicanalíticas ainda pouco conhecidas em certos campos e, por vezes, deturpadas pelas estigmatizações que a psicanálise sofreu ao longo dos tempos, que podem ser aplicadas a contextos clínicos. Através desses estudos somados à recente experiência com as VVF's, apresentaremos a proposta de novos modos de intervenção com o "trabalho em ato com o luto" (Alouch, 2004), no contexto da prática clínica hospitalar.

Seguindo as perguntas de Freud (1926), se uma reação à perda de objeto é o luto, e sua natureza é particularmente dolorosa, quando é que a separação do objeto traz angústia, luto ou apenas dor? Mesmo sem respostas imediatas para a pergunta, Freud faz algumas demarcações e indicações que iremos trazer para discussão. A fim de melhor elucidar esta temática, traremos algumas obras cinematográficas que abordam o luto: "Anticristo" (2009), "Melancolia" (2011) e "Pedaços de uma mulher" (2020). Estes filmes tratam das vicissitudes do luto quando não se pode reconhecer que o "objeto perdido" não se trata de qualquer objeto, mas de algo com valor agalmático, fálico, um "pedaço de si", invocando a perspectiva de uma "Erótica do Luto", tal como apresentada por Alouch em seu livro.

A aposta que se faz é poder dar ao luto um estatuto de produção de vida e de subjetivação diverso às ideologias patologizantes e classificatórias, sem desconsiderar os processos psíquicos complexos e outros sofrimentos que, por vezes, se misturam ou confundem.

Trivium: Estudos Interdisciplinares, Ano XIII, Ed. 2. p. 49-61. 


\section{O Luto não é obvio!}

"Deixe que eu chore/minha sorte cruel/e que eu suspire/pela liberdade! / Que a dor quebrelestas cadeias/de meus martírios, /só por piedade!"

No prólogo do filme Anticristo (2009), ouve-se a ópera Rinaldo, de Händel, de 1711, trazendo a ideia de que algum fato de tristeza se passaria no filme. O filme Anticristo (Antichrist) é uma das obras do cineasta Lars von Trier, lançado em Cannes em maio de 2009. A atriz principal, Charlotte Gainsbourg, ganhou o prêmio de melhor atriz, mas o filme foi extremamente criticado, inclusive o autor foi acusado de "misógino" e hostil. A própria imprensa brasileira fez constatações de que o filme era "tristemente inconsciente, de rasas forças simbólicas, patéticas, e de extrema obviedade de suas implicações existenciais e filosóficas" (Valente, 2009, apud Kruger, 2014, p. 57).

Já na primeira cena do filme, aparece a história do casal que ao fazer sexo, não percebe que seu filho, um bebê, lança-se através da janela. Os personagens, que não recebem um nome, logo em seguida aparecem na cena do enterro. A mãe desmaia e não vela a perda do filho e é levada para o hospital, onde seu marido, interpretado por Willem Dafoe, faz também um papel de terapeuta comportamental e assume a tarefa de livrá-la de seus medos e "ataques de ansiedade". A mãe, ao enterrar o filho e desfalecer, não chora a sua perda. Por outro lado, o pai no papel de terapeuta, parece passar também por cima de sua dor. Seguem para a cabana do casal em meio a uma floresta, onde o filme vai transcorrer e onde a suposta "loucura" da personagem vai aparecer e reinar o caos.

O filme traz em cena os sofrimentos da personagem com uma certa indefinição se os mesmos seriam da ordem de um luto pela perda do filho ou de uma melancolia, com fenômenos delirantes/alucinatórios, loucuras projetadas e vividas a dois, fugas da dor e dores infligidas no corpo. Culpa, raiva e tristeza são sentimentos que aparecem (e são comuns em processos de perdas),

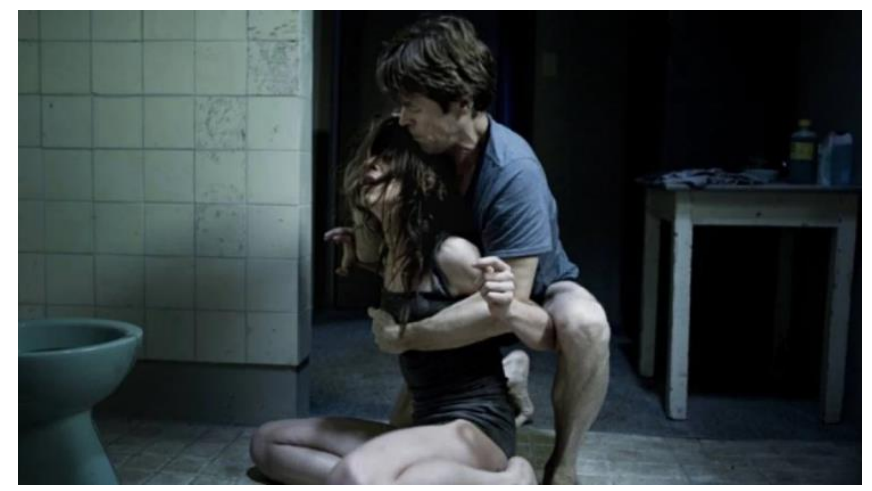

Cena do filme "O Anticristo" mas que sem elaboração irrompem em ataques de fúria, autoagressões e agressões ao outro. Traz à baila as insígnias da pulsão de morte, das relações de objeto, do desamparo e da própria morte, com algumas tentativas de criação e reparação frustradas.

Cabe dizer que, em outro filme, do mesmo autor, intitulado Melancolia (2011), duas irmãs afastadas pelo tempo, têm reações completamente distintas ao saber que o mundo está chegando ao fim pela possível colisão de um planeta chamado Melancolia com a Terra. Uma aceita calmamente a situação enquanto a outra se desespera. No filme, a personagem que se demonstrou melancólica o filme todo, diante da aproximação da destruição do planeta, lança mão de uma "caverna mágica" diante do fim trágico, numa espécie de proteção, mesmo que imaginária, mas que traz um anteparo ao horror do desamparo.

No Anticristo, a Cabana, não parece exercer a mesma função. Cenas eróticas mesmo em frente à morte da criança, parecendo meio que desconectadas, mas que demonstram a assertiva de que "sexo e morte não têm registro no inconsciente" e por isso, não cessam de fazer apelo à representação. São significantes que não se remetem a outros, 
como disse Lacan: "Pois que a presença do sexo está ligada à morte". Tanto que a tradução da expressão francesa "petite mort" seria "orgasmo" na língua portuguesa. Lacan mesmo colocou que a linguagem sempre vela "o que ela sempre vela é, em última instância, a morte" (LACAN, 1958-59, p.33).

Como poetizado pelo filósofo La Rochefoucauld, "Nem o sol, nem a morte, podem ser vistos de perto" e refletido por Freud em "Considerações contemporaneas sobre a guerra e a morte":

Mostrávamos a tendência inconfundível de deixar a morte de lado, de eliminá-la da vida. Tentávamos matá-la com silêncio. É que a própria morte é irrepresentável, e sempre que fazemos essa tentativa, é possível perceber que continuamos lá como espectadores[...]. No fundo, ninguém acredita na própria morte: no inconsciente, cada um de nós está convencido de sua imortalidade (FREUD, 1915, p. 117).

Se a morte não pode ser observada e simbolizada, quais seriam as consequências para a economia psíquica e quais mecanismos operariam diante de uma perda? Quando é que a separação traz angústia, luto ou dor? Se a tristeza é aparente e a angústia o afeto que não engana, seria o luto um acontecimento óbvio? Creio que não.

Uma maçã quando partida ao meio apodrece, mas as sementes resistem e se forem adubadas, darão novos e frondosos frutos! Existe, todavia, todo um processo para que isso aconteça. $\mathrm{Na}$ vida humana, as perdas afetivas por mortes levam a estados de muita dor e desesperança; por outro lado, semelhantemente à outras formas naturais de vida, ali onde um pedaço do sujeito parece ter sido arrancado, pode nascer algo profundo e transformador. Para isto, o luto precisa ter o seu lugar. Abordarei um filme que vai ilustrar essas questões, afinal, "no domínio da ficção encontramos a pluralidade de vidas de que necessitamos" (FREUD, 1915, p.120).

No filme "Pieces of a Woman" (Pedaços de uma mulher), lançado em 2020 pela Netflix e dirigido por Kornél Mundruczó, retrata a estória de uma mãe que perde seu bebê após o nascimento, e precisa insistir para que possa viver a dor da perda ao seu modo, da qual estava sendo impedida. A dor do luto é difícil de se suportar, mas não poder atravessá-la impõem em novos sofrimentos. É preciso "re-lutar" pelo luto. É uma relutância na atualidade, quase que da ordem da militância. $\mathrm{O}$ ato de sacrifício é de extrema importância para a economia psíquica e a continuidade da vida daqueles que ficam.

O casal Marta (Vanessa Kirby) e Sean (Molly Parker) está à espera de sua primeira filha, em um parto doméstico. As cenas vão retratando as angústias do momento, as dores, configuradas pelo dia frio e chuvoso, que culmina com o atraso da parteira. A tensão que é retratada no filme e a mistura de sentimentos de medo e alegria, não diferem de muitos outros que as pessoas passam em períodos gestacionais. Embora não seja abordado, às vezes "o fim da vida vem no começo dela" ! O casal sofre a perda do filho minutos após seu nascimento. Num primeiro momento, ficam perplexos, mas, em seguida, sobrevém a raiva e a revolta contra a parteira. No decorrer do filme, Marta e Sean passam a lidar com seus lutos de forma distinta o que leva à separação do casal. Conflitos familiares vêm à tona e se somam a estes. Marta expressa em sua face e angústia, a dor da perda, que representa "Um pedaço de si" que se foi contra o seu desejo. Seu sofrimento não estava sendo compreendido e trazia ares de um estado depressivo; Marta, porém, estava em luto. Lutando e relutando para vivê-lo. Não se deve interromper, tampouco acelerar um processo à despeito de se retornar à vida feliz e produtiva de sempre. O luto tem o seu tempo. O enlutado quer chorar, quer se isolar, ficar na cama, não comer. Aos poucos, isso 
se vai recobrando, com amor, com cuidado, respeito. Este filme, diferentemente do Anticristo, tem um final mais otimista. Quando Marta foi ao tribunal depor contra a parteira, durante o inquérito, o advogado de defesa lhe pergunta como se sentiu quando segurou sua filha? Pela primeira vez, alguém conseguiu fazer com que ela reconhecesse seu próprio sentimento. Marta responde à pergunta com uma metáfora: "ela tinha cheiro de maçã̃". O cheiro da maçã veio a ser um significante repleto de significações para

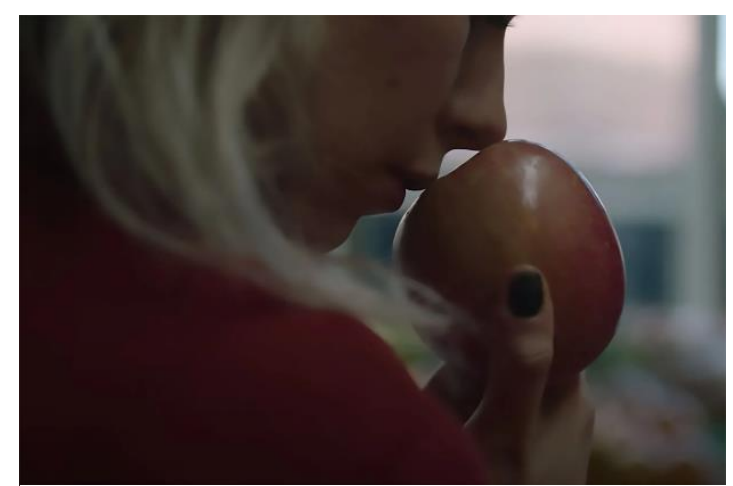

Cena do filme "Pieces of a Woman" Marta. A metaforização trouxe outro estatuto para o objeto fálico (para alguém que ocupou esse lugar), com efeitos apaziguadores. Em seguida, conseguiu ver o negativo da foto com a bebê no colo, e após revelar a foto, chorou e pôde até sorrir. Retornando ao júri, depõe:

[...] essa mulher teve a intenção de fazer um parto saudável, ela não tem culpa. Seja qual for o motivo da morte da minha filha, não vamos achá-lo aqui nesta sala. Se eu aceitar alguma compensação financeira por isto, estarei dizendo que a minha perda pode ser recompensada, e ela não pode. Nada vai trazê-la de volta. Não posso provocar uma dor nessa pessoa, não é isso que minha filha ia querer ao vir ao mundo, pelo tempo em que veio.

Alguns dias depois, Marta conseguiu jogar as cinzas da filha ao mar. A personagem, ao conseguir atravessar sua dor, reconstrói sua vida, que foi representado pela linda macieira em seu jardim (ela amava maçãs) onde uma criança brincava, sua segunda filha. Fazer a travessia de um luto requer coragem para enfrentar e buscar recursos internos e externos. Lembrando: "não há nada que possa preencher com significante esse furo no real, se não for a totalidade do significante, o trabalho do luto se apresenta como algo que acontece dentro da desordem onde faltaram elementos significantes" (Lacan apud Alouch, 2004, p. 276). É colocado em jogo todo o sistema significante em torno do mínimo luto.

Segundo Freud (1915), "a consideração pelo morto, nós a colocamos acima da verdade, e a maioria de nós a coloca acima da consideração pelos vivos". Essa posição pode ser constatada com o nosso "colapso total" quando a morte atinge uma pessoa próxima- pai, irmão, cônjuge, filho ou um amigo querido. "Enterramos com ele as nossas esperanças, pretensões, prazeres, não nos deixamos consolar e nos recusamos a substituir aqueles que perdemos. Conduzimo-nos como uma espécie de Asra, que também morre quando morrem aqueles que ama” (FREUD, 1915, p.119).

\section{Por uma abordagem diferencial do Luto}

"A morte já não se deixa mais renegar [verleugnen]; temos de acreditar nela. Os seres humanos realmente morrem, e não mais um a um, mas muitos, às vezes dezenas de milhares num só dia. Não se trata mais de nenhum acaso" (FREUD, 1915, p.120).

A questão da morte em seu processo histórico sofreu transformações a partir do século XIX e a incidência do luto foi deslocada do espaço doméstico para ter a sua vivência depois dos funerais e do enterro. Segundo Ariés (1975), "a dor da saudade no coração do sobrevivente não devia mais ser manifestada em público, segundo a regra 
adotada em todo o ocidente, exatamente o contrário do que era anteriormente". A morte e o luto passaram a ser tratados com a mesma pudicícia que os impulsos sexuais há um século. A supressão do luto do espaço público deveu-se a um constrangimento impiedoso da sociedade, com a recusa a participar da emoção do enlutado, recusando-se a morte, mesmo admitindo sua realidade (GORER, apud ARIÉS, 1975, p. 782).

O luto é sempre uma questão complexa, que por vezes pode passar indiferenciada ou se assemelhar a outros acometimentos. Freud diz que "a dor é reação à perda do objeto e a angústia, ao perigo que esta perda traz consigo, e em deslocamento, ao perigo da perda do próprio objeto". Neste ponto, Freud (1926) afirma que o luto é uma reação emocional à perda de objeto: "ele surge por influência do exame de realidade que exige que o indivíduo se se separe do objeto; cabe ao luto a tarefa de executar esse desprender-se do objeto". Mas como ele próprio coloca, os seres humanos não se desprendem de seus objetos amorosos assim de bom grado! (Freud, 1917[1915], p.101)

$\mathrm{O}$ interdito da morte e a inconveniência do luto, fizeram com que a obra de Freud (1917[1915]) "Luto e Melancolia" tenha sido bem acolhida neste momento, ligando o luto ao contexto histórico mais do que propriamente particular. O "trabalho do luto" ganhou força nos tempos dos funerais (Ariés, 1975, p.590). "Luto e Melancolia", trouxe além das concepções de "trabalho de luto", a da tristeza como seu afeto normal, também presente na melancolia, tentando diferenciá-la pelo seu caráter de patológica. O luto seria normal e teria um fim, embora ele traga consigo desvios quanto à conduta normal na vida. É suposto que isto salvaria os enlutados das classificações psiquiátricas, como portador de um certo tipo de loucura relacionada à doença mental. Tentando diferenciá-los, Freud descreveu que:

Na melancolia ocorre um profundo abatimento, com uma cessação do interesse pelo mundo exterior, perda da capacidade de amar, inibição de toda atividade e diminuição da autoestima, com autorrecriminações por vezes delirantes e punitivas; o luto exibiria os mesmos traços, exceto que nele a autoestima não seria afetada" (Freud, 1917[1915], p.100).

O trabalho realizado pelo luto exige que toda libido seja retirada de suas conexões com o objeto perdido, vencendo o afastamento da realidade aos poucos, com dispêndio de tempo e energia. Enquanto isso o objeto perdido se prolonga na psique, até que a libido seja desligada pouco a pouco e se consuma o trabalho de luto, entretanto, essa tarefa solicitada pela realidade, não pode ser realizada imediatamente. Trata-se de uma operação de compromisso extraordinariamente dolorosa.

Na melancolia, a perda do objeto é de outra natureza: a perda do objeto é subtraída a consciência, não se sabe o que perdeu, ao passo que no luto nada é inconsciente na perda. Diferentemente do luto também, na melancolia a libido livre não é deslocada para outro objeto, mas recuada para o Eu, identificando-se com o objeto abandonado: a sombra do objeto recai sobre o Eu. A melancolia toma emprestada, portanto, uma parte de suas características do luto. Como no luto ela é a reação a perda real do objeto, mas além disso, está comprometida com uma condição que falta no luto normal, ou quando presente, converte-o em luto patológico.

Um ponto de aproximação entre o luto e a melancolia pode ser descrito pelas características da "psicose alucinatória de desejo", que pode aparecer no luto, que como diz Alouch (2004), "trata-se de uma experiência de afastamento da realidade que faz assegurar a permanência do objeto no psiquismo"; "no luto normal, assim como na neurose obsessiva, vai haver o respeito a esta realidade". Alouch faz alusão ao termo "luto

Trivium: Estudos Interdisciplinares, Ano XIII, Ed. 2. p. 49-61. 
melancólico", explicando o caráter do objeto de amor ser perdido desde sempre, e colocado por Lacan (1960) como um objeto insubstituível, porque faltoso.

Existem estados de sofrimento que não se inscrevem psiquicamente, inviabilizam a subjetivação, não encontram meios para se integrar ao simbólico. Existiriam saídas para que novas subjetividades possam ser construídas nestes estados sem que sejam rotuladas, classificadas ou patologizadas de antemão? O que poderia corroborar para que um luto seja respeitado, reconhecido e elaborado de modo a mediar certos sofrimentos, sem o intuito de apressá-lo e nem tampouco interrompê-lo evitando assim suas complicações? Existe um Furo, e ele é Real.

Trata-se de um lugar onde o sujeito pode despejar todo tipo de coisas, as imagens e significantes colocados em jogo no trabalho de luto. Fracassamos enquanto não tivermos entendido que tudo o que for despejado nesse furo jamais o preencherá. $\mathrm{O}$ trabalho do luto não é o alfa nem o ômega do luto (Alouch, 2004, p.275).

É muito comum, nos processos de luto, as pessoas quererem dar conselhos, dizer palavras e expressões no intuito de acalentar o enlutado, que vêm repletas de significados para quem fala e não necessariamente para o outro. Algumas vezes, o próprio enlutado busca subterfúgios para não viver a dor da perda ou a vive de forma avassaladoramente solitária entregando-se ao grande vazio instalado. Existe toda uma travessia de sentimentos e emoções controversas, de reações diante de notícias ruins, até que encontre apaziguamentos e a "aceitação" da perda, sendo que esta muito dificilmente acontecerá no início do luto. Mesmo que certas vivências tragam antecipações ao luto, cada um vai dar sua resposta subjetiva em um tempo que não segue uma cronologia exata, mas que pode ter seu instante de conclusão. Essa questão de pôr um termo ao luto tem sido objeto de críticas por outras teorias, mas é importante entender a noção de temporalidade e o suposto "fim" do luto para a Psicanálise; o que Freud quis transmitir quando trouxe essa questão poderá ser melhor explicitada com a asserção do tempo lógico em Lacan, em que o tempo de concluir, trata-se de uma instância que sucede aos dois tempos primeiros - ver e compreender, que abrem espaço para o trabalho de significantização de uma perda. Trata-se mais da inclusão de significantes do que de dar sentidos ou significados. Exploraremos tudo isto mais adiante, mas antes faz-se necessário identificar o luto na cadeia afetiva.

Freud (1926), em "Inibição, Sintoma e Angústia", traz o exemplo do bebê que avista uma pessoa desconhecida no lugar da mãe. Este bebê sente medo diante do perigo da perda de objeto. Não há dúvida quanto à angústia do bebê, mas a expressão facial e a reação de choro permitem supor que ele sente dor também. Ele não é capaz de distinguir a ausência temporária da perda duradoura; se perde a mãe de vista acha que nunca mais vai vê-la. A brincadeira da mãe de ocultar o rosto e depois aparecer vai ensinando-o a não se desesperar embora o anseio esteja presente. Para ele, sentir falta da mãe não é uma situação de perigo, mas sim traumática, caso no momento ele tenha alguma necessidade que a mãe deveria satisfazer, podendo então se transformar em situação de perigo. Diz Freud, portanto, a primeira condição para a angústia que o Eu introduz, é a perda da percepção do objeto, que equivale à da perda do objeto. Mais tarde, a experiência pode ensinar à criança que o objeto continua existindo, estando o pequeno sujeito zangado pela perda do amor do objeto. Mais um novo e persistente perigo e condição de angústia. Diferentemente da situação traumática do nascimento, não havia objeto que pudesse fazer falta, a angústia era a única reação que podia ocorrer. A novidade desta outra situação é a reação da dor.

Trivium: Estudos Interdisciplinares, Ano XIII, Ed. 2. p. 49-61. 
A dor interna, psíquica é equiparada à dor física em seu sentido da perda de objeto. $\mathrm{Na}$ dor física, há um forte investimento no local dolorido do corpo, um investimento narcísico. Tanto que pessoas sentem fortes dores no peito, no coração, e é comum ouvir por exemplo: "não perdi apenas meu marido, mas perdi o amor da minha vida". O sujeito não terá então, "perdido alguém, mas além disso, ademais, em suplemento, um pequeno pedaço de si" (Alouch, 2004, p. 285).

Não há nada que possa preencher com significante esse furo no real, se não for a totalidade do significante. $\mathrm{O}$ trabalho cumprido no $\log o s$ (onde o grupo e a comunidade são seus suportes), o trabalho do luto se apresenta como algo que acontece dentro da desordem onde faltaram elementos significantes para fazer frente ao furo criado; é colocado em jogo todo o sistema significante em torno do mínimo luto (Alouch, 2004, p.276).

Não se trata apenas de um trabalho de luto, no sentido de um ato seco, mas da subjetivação de uma perda. Efetuar no sujeito uma perda sem qualquer compensação, é uma perda seca. Na ausência de rito a seu respeito, a selvageria tem por contrapartida fazer com que a morte induza o luto a um ato seco, sem simbolização. Isso pode ser visto no filme o Anticristo, onde o sofrimento pela morte da criança foi "diagnosticado" como ansiedade. Embora a personagem demonstrasse angústia e dor pela perda do filho, ela não parecia reagir emocionalmente a esta perda, ou melhor, não havia distinção entre o sofrimento pela morte do filho com outros sofrimentos de sua estória. Não é claro o lugar que a criança ocupava no desejo dos pais, mas possivelmente, o sinal de "sacrifício" aparecia de uma forma não simbolizada, em acting out, pela via da agressividade.

Segundo o Dicionário Enciclopédico de Psicanálise:

Quando um sujeito não consegue lembrar de um elemento recalcado ele age por vezes sem saber o que está retornando na forma de ação. Freud nomeia essa atuação pelo termo Agieren, expressão com sentido teatral. Dentro ou fora de análise é uma dimensão que reproduz um clichê ou um roteiro inconsciente e possui dimensão transferencial. Pode constituir um apelo atestando uma incapacidade do dizer, correspondendo a uma intervenção no real. Representa uma verdade não reconhecida, situando-se na fronteira entre a vida real e a ficção (Kaufman, 1996, p.4).

O luto não é óbvio, no sentido de que ele segue uma lógica do inconsciente nem sempre perceptível sem a escuta analítica. Seu sofrimento precisa ser reconhecido para que seja legitimado e possa ser vivido.

\section{Do "luto antecipatório" à asserção da "certeza antecipada"}

O termo "luto antecipatório" foi cunhado por Linderman (1944) para denominar a ausência de manifestações claras do luto no momento real da morte, em pessoas que já vivenciaram o luto normal. Foi posteriormente aprimorado pelo psiquiatra Knigth Adrich (1963), como o luto do paciente que está morrendo. Worden (2013, p. 146), definiu-o como "um luto que ocorre antes da perda de fato, distinto do luto normal". Muitas mortes acontecem com algum prenúncio e durante esse período de antecipação o indivíduo inicia a tarefa do luto e começa a vivenciar várias respostas do luto (Worden, 2013). O luto prémorte não encurta nem ameniza o processo de luto, mas pode vir a ser um mediador para seu fortalecimento e resultado (Hogan, Morse e Tason,1996 apud Worden, 2004). Nesta etapa, a consciência da inevitabilidade da morte pode alternar com experiências de 
negação de que o evento vá mesmo acontecer; por outro lado, há pessoas que mantém a esperança e reforçam a negação, aumentando a ansiedade de separação. No entanto, perguntas como: "como vou ficar sem ele", podem fazer um "ensaio" que Janis (1958) chamou de "trabalho de preocupar-se". Frases como "Oh, não se preocupe, tudo ficará bem", podem interromper esse trabalho.

Elisabeth Kluber-Ross (1926/1989) dedicou-se ao estudo de pacientes terminais investigando como lidavam com a proximidade da morte, observou que todos os pacientes reagiram da mesma forma com relação às más notícias- com choque e descrença e mapeou quatro posições que não são específicas para a doença, mas "maneiras que os humanos dispõem para enfrentar crises, receber notícias ruins, lidar com mudanças, encarar a morte e reagir à doenças", sendo elas: a negação, a barganha, raiva/revolta, depressão e a aceitação e esperança. Embora conhecidas como "etapas" do luto, não são lineares. Em sua obra "On Grief \& Grieving" (2005/2014), Elizabeth localizou na antecipação do luto, o "começo do fim", também entendia que o luto não tem exatamente um fim, sendo constantemente ressignificado ao longo da vida dos que ficam. Sentimos tristeza e precisamos preparar a psique. Para a autora, o luto antecipatório é mais silencioso do que o luto após a perda, é pouco verbalizado. É uma experiência de viver o limiar da perda diante de doenças terminais, quando o paciente não está bem, mas ainda não morreu; a saúde está frágil, mas ainda tem alguma qualidade de vida, podendo levar meses ou anos. Este tempo pode ser usado de modo benéfico e impactar no luto subsequente, quando se é encorajado a cuidar de questões inacabadas (Kübler-Ross, 1998).

Em "Função e campo da fala e da linguagem" (Lacan, 1953), apostou na potência apaziguadora das palavras, dizendo que "nada há de criado que não apareça na urgência e nada na urgência que não gere superação pela fala". Ao pensar o tempo lógico no campo do atendimento psicanalítico no hospital, na urgência da queixa, pode-se encontrar a ocasião em que o sujeito se vê imerso no desamparo (Moura, 1996). Na escansão do tempo lógico, o tempo é um evento significante, cujo tempo privilegiado na análise, é o tempo de concluir. Na práxis da urgência, "clínica das pessoas que no momento do desespero, não falam, e se fala, não articulam a fala ao dizer" (Moura, 1996, p. 10), o tempo de ver e o de concluir, são insuportáveis para o sujeito, e o analista, sob o paradigma do tempo lógico, irá privilegiar o tempo de compreender.

Lacan (1945), em "O tempo lógico e a asserção da certeza antecipada", traz no sofisma dos três prisioneiros, a função da pressa como dimensão temporal do sujeito. Os prisioneiros logo após se olharem (tempo de ver), põem em dúvida sua solução, num segundo tempo (tempo de compreender). A seguir, no tempo de concluir, repetem de forma conjunta a solução. Esses dois últimos de tempos de escansão têm para os sujeitos o valor de significantes, que favorecem as marcações simbólicas que os compelem a concluir na pressa.

O tempo de ver é um tempo zero, "momento de fulguração onde o sujeito em questão é impessoal" (Lacan, 1945, p. 202). No tempo de compreender, a hipótese se cristaliza e o sujeito é pareado, indefinido e recíproco. Esse tempo inaugura a dimensão imaginária desse outro, no qual o sujeito se reconhece. No tempo de concluir, o sujeito do enunciado coincidindo com o sujeito da enunciação, se declara o que é, momento que marca a constituição do sujeito.

Cada prisioneiro, no sofisma, experimenta um momento de vacilação em seu raciocínio. Tem medo de ser ultrapassado pelos outros, caso não o faça rapidamente. $\mathrm{Na}$ pressa, o sujeito recai sobre o ato da certeza antecipada. É no a posteriori das escansões que o sujeito sabe que sua asserção terá sido válida. Em "Posição do Inconsciente" (Lacan, 1998), Lacan adota o corte das sessões, propondo a escansão da sessão como um 
momento eficaz de intervenção e interpretação analítica, na assertiva de que "a transferência é uma relação ligada ao tempo e a seu manejo" (Lacan, 1945, p. 858). Neste ato, o analista não apenas opera como corte, mas também com toda dimensão temporal implicada para o sujeito do inconsciente. No sofisma apresentado pelo analista, a conclusão se apresenta como uma solução lógica quando se consideram as escansões suspensivas.

A tentativa de inserir a ruptura do sujeito lançado ao desamparo, na cadeia significante do sujeito, requer a especificidade do ato analítico. Através do ato e sua lógica, o analista na urgência, irá tentar trabalhar para que o tempo de compreender se faça. No tempo de compreender o sujeito é mais da ordem do eu imaginário que se espelha no outro. Privilegiando esse tempo, é possível que o sujeito tenha um ancoramento significante, se constituindo em certos modos de articulação em relação com o tempo (Silva, 2003).

\section{“Que te sirva de vela!": Luto em ato na Pandemia da Covid-19}

A utilização das VVF's no período de pandemia constituiu o único meio de comunicação entre pacientes e famílias. Diante desse cenário, os hospitais suspenderam temporariamente as visitas presenciais, trazendo novos sofrimentos para os pacientes hospitalizados e seus familiares. Para as pessoas acordadas e que desejam essa interação, é realizada uma ou mais abordagem, com escuta antes e depois, bem como à família. Em outros casos, utilizam-se áudios onde as famílias, falam, desejam melhoras, fazem orações e declarações amorosas. Isto diminuiu muito as angústias por não poder ver, tocar, se despedir antes da morte. As vítimas de Covid-19 têm velórios rápidos e com caixão fechado, tendo que reconhecer corpos através de fotos.

Douglas, um rapaz de 30 anos, músico, à espera do seu primeiro filho, pôde comunicar-se com a esposa, a mesma em uma gestação de risco, desde sua chegada à enfermaria até a UTI. Maria estava em extrema angústia e sentia dores na barriga, não parava de chorar, não comia, não dormia. Após alguns dias, Douglas precisou ser intubado e não puderam mais se falar. Maria enviava áudios e músicas do próprio Douglas cantando, contava o tamanho e peso do bebê, enviava seus batimentos cardíacos. Maria perguntava ao marido como ele estava suportando deixar uma grávida cheia de desejos, sozinha em casa. Ela já estava preparando o prato predileto dele, camarões na moranga. Douglas arregalou os olhos de felicidade e pediu que o esperasse com uma festa. Ambos fizeram declarações de amor e se despediram com "beijos virtuais". São instantes de sofrimento que parecem se transformar em momentos de felicidade e esperança. "Sentese o amor no ar". Algumas semanas depois, Douglas vem a óbito devido a complicações pulmonares. Maria, que já estava sendo amparada pela equipe de Psicólogos, é acolhida também no momento da perda. Com toda sua dor, ainda foi capaz de agradecer pelo cuidado que lhe foi oferecido. Decidiu não olhar a foto e ficar com a última imagem do marido que printou na tela durante a videochamada.

"Que te sirva de vela!", como colocado por Alouch (2004). Kenzaburô Ôe caracteriza esse ato como "gracioso sacrifício de luto". O enlutado efetua sua perda com um pequeno pedaço de si; "nem de ti, nem de mim, mas de si" (Alouch, 2004, p.12). Esse pequeno pedaço de si pede uma "erótica do luto", um "pequeno" e desafiante falo está no cerne do sofrimento do luto. O luto na psicanálise, por essência tem um fim. Ao voto de abandono após a perda de algo que lhe foi tirado, o luto responde, ato por ato, nomeando esse "pequeno pedaço de si". O objeto perdido no luto tem o estatuto de objeto desejável, de agalma, que pela falta brusca, violentamente se transforma em desejante, mesmo não querendo sê-lo. Lacan, sobre o banquete de Platão, vai se referir ao agalma, erastes e 
erômenos. Erastes passeava tranquilamente com o objeto agalmático roubado enquanto erômenos lhe diz: "Que isto te sirva de vela... para teu enterro"! Ambos ficam quites, já que uma báscula se operou, e a reação ao ato, o que resta é que "um fim teve lugar". O assunto está encerrado, cada um pode cuidar de suas preocupações (Alouch, 2004, p.14).

O objeto intempestivamente arrancado, serve de vela ao tomador no momento em que for ofertá-la, na morte. A morte outorga estatuto de dom ao objeto que foi arrancado, e o vivo segue desejando. Para isto, um ritual deve ser feito, a fim de cumprir uma simbolização. Velar pode assumir vários significados: olhar com um véu, dar uma luz, um pouco menos sombria e ofuscante, e apontar para algo que brilha em outro lugar.

Com as videochamadas, mediadas pela escuta, os instantes de ver, compreender e concluir tornam-se viabilizados. O "fim" viria no momento de concluir, para que o sujeito possa sair da inibição, apatia, procrastinação e possa agir. Não quer dizer que a perda não seguirá em elaboração, pelo contrário, é o salto para que haja a entrada de significantes onde não há.

Situamos o luto enquanto experiência erótica. No luto, a convocação do falo não faz com que ele seja identificado, mas abre a possibilidade de seu sacrifício. Efetua-se esse sacrifício pelo ato, que põe fim ao luto. "Esse sacrifício de si mesmo, essa libra de carne comprometida em sua relação com o significante, é porque algo vem ocupar o lugar disso que esse algo se torna objeto no desejo".

A Psicanálise ao considerar como seu objeto, o objeto $a$, no campo do inconsciente, diferentemente da medicina cuja ação científica está no campo do olhar para a doença, consegue depreender a ação de um trabalho como os das VVF's. "Eles não têm olhos para não ver, que as coisas têm a ver com eles, que elas os olham" (Lacan, 1964, p. 106). No campo escópico, o olhar está do lado de fora, sou olhado, sou quadro. O que me determina fundamentalmente no visível é o olhar que está do lado de fora. Se não sou visto, não sou desejado. Não existo.

Para o luto ser situado numa experiência erótica, é preciso convocar para o lugar da perda algum ser fálico, para poder sacrificá-lo, entregá-lo. No filme Anticristo, o filho não representou o falo para a mãe, nada veio ocupar este lugar. Nem tese, nem marido, nem terapia. Não houve luto, apenas angústia e dor, e um sofrimento semelhante ao da melancolia "quando a sombra do objeto recai sobre o Eu". Sem nenhum anteparo, com as marcas de uma catastrofização.

Através dos aparatos possibilitados pelas VVF's no hospital, famílias e pacientes, toda a equipe de saúde envolvida, é possível ver e sentir o amor nas despedidas. Eis um desejo que se presentifica, que se coloca em ato, e produz algo de diferente- como o de Marta no filme e tantas outras pessoas que não deixam de velar seus mortos. O anteparo aqui é o lugar da mediação. Uma espécie de prótese imaginária que oferece proteção ao Real, um contorno, mesmo que algo de inexorável escape. Os três tempos lógicos operam a partir da escuta analítica e demonstram seus efeitos- entrega, gratidão, gestos de amor e significantes fálicos: "o fruto do nosso amor está no meu ventre", disse a esposa do paciente Diego. "Ele pode ir em paz"! E o amor é marcado pela metáfora, naquele ponto do Real onde somente a sublimação e o ato criativo podem comparecer, fazendo véu ao vazio insustentável.

Isso significa que o trabalho do luto termine neste momento? Não necessariamente. Ele pode avançar de acordo com o modo particular de cada um, a recorrência de seus sentimentos e recordações. Conforme demonstrado pela escansão do tempo lógico, o próprio tempo torna-se um evento significante. Na práxis da urgência, o tempo de ver e o de concluir, insuportáveis para o sujeito, podem ser amparados pelo tempo de compreender.

Trivium: Estudos Interdisciplinares, Ano XIII, Ed. 2. p. 49-61. 
O luto tem uma complexidade e, para isso, não existem verdades absolutas. Há sempre algo de enigmático e surpreendente nos modos de subjetivação a advir. Cada sujeito vai viver seu luto com sua singularidade mesmo que em seu processo histórico existam imperativos para que padrões sejam seguidos. Nas histórias de luto, narrativas contam histórias de vida, histórias de amor. Portanto, mesmo quando a pulsão encarna sua vertente mortífera, podemos ainda invocar Eros!

\section{Referências}

Allouch, J. (2004). Erótica do Luto. No Tempo da Morte Seca. Rio de Janeiro: Companhia de Freud.

Ariès, P. (2017). Sobre a História da Morte no Ocidente Desde a Idade Média (P.V. de Siqueira, Trad.). [Ed. Especial]. Rio de Janeiro: Nova Fronteira.

Freud, S. (2020) "Por que a guerra". In: Cultura, Sociedade, Religião. O Malestar na cultura e outros escritos. Belo Horizonte: Autêntica. (Original publicado em 1933)

Freud, S. “Inibição, sintoma e angústia”. In: Obras completas, Vol. 17. (Original publicado em 1926)

Freud, S. (2020). "Luto e Melancolia". In: Neurose, psicose, perversão. Belo Horizonte: Autêntica, 2020. (Original publicado em 1917)

Kaufman, P. (1996). Dicionário enciclopédico de Psicanálise. O legado de Freud e Lacan. Rio de Janeiro: Jorge Zahar Ed.

Klüber-Ross, E \& Kessler, D. On Grief \& Grieving. (2014). Finding the meaning of Grief Through the Five Stages of Loss. New York: NY.

Klüber-Ross, E. (1998). Sobre a morte e o morrer. São Paulo: Martins Fontes. 1998.

Kruger, P.A. (2014). A Projeção da Loucura na figura feminina em Anticristo, de Lars Von Trier. Revista Criação \& Crítica. Universidade de São Paulo Faculdade de Filosofia, Letras e Ciências Humanas - Departamento de Letras Modernas. https://doi.org/10.11606/issn.1984-1124.v0i13p55-68.2014.

Lacan, J. (1998). O Seminário livro 11: Os quatro conceitos fundamentais da Psicanálise. Rio de Janeiro: Zahar. (Originalmente publicado em 1964)

Lacan, J. (2016). O Seminário livro 6: O Desejo e sua interpretação. Rio de Janeiro: Zahar. (Originalmente publicado em 1958-59)

Lacan, J. (1998). “O Tempo lógico e a asserção da certeza antecipada”. In: Escritos. Rio de Janeiro: Zahar. (Originalmente publicado em 1945)

Moura, M.D. (Org.) (2003). Psicanálise e Hospital. TEMPO E MORTE. Da urgência ao Ato analítico. Rio de Janeiro: Revinter.

Silva, I.E.B. (2018). O paciente não é só o paciente; Ele é o amor de alguém! http://redehumanizasus.net/o-paciente-nao-é-só-um-paciente-ele-é-o-amor-dealguém/2018 
Worden, J.W. (2013). Aconselhamento do Luto e Terapia do Luto. Um Manual para Profisssionais da Saúde Mental. Quarta Edição. São Paulo: Roca.

Notas:

1. Vide o livro: BUTINHOLLI, C. Uma Coreografia de Emoções: narrativas de um trabalho no hospital. Rio de Janeiro: Ed. Multifoco, 2019.

Citação/Citation: Rangel, C. B.; Loures, J. M. T. (2021). Por uma erótica do fim: luto no contexto da pandemia de COVID-19. Trivium: Estudos Interdisciplinares (Ano XIII, Ed.2), pp. 49-61.

Recebido em: 08/07/2021

Aprovado em 23/08/2021

Trivium: Estudos Interdisciplinares, Ano XIII, Ed. 2. p. 49-61. 